\title{
THE EFFECTS OF DEMOGRAPHIC CHARACTERISTICS ON ORGANIZATIONAL COMMITMENT AND JOB SATISFACTION: AN EMPIRICAL STUDY ON TURKISH HEALTH CARE STAFF
}

\author{
FIKRI PALA \\ SEMIH EKER \\ MELEK EKER
}

\begin{abstract}
Uludağ Üniversitesi, İïF,
Özet:Bu çalışma Türk sağlık sektöründe belirlenen bir örneklem vasıtasıyla, organizasyonel bağlılık, iş tatmini ve demografik özellikler arasında ilişki ve farkıııkları ortaya koymaktadır. Veriler, Bursa'da 3 hastanede görev yapan 473 sağlık hizmetleri çalışanlarından, sosyo-demografik anket formu, "Örgütsel Bağlıık Envanteri" ve "Minnesota İş tatmin" ölçeği kullanılarak toplanmıştır. Verilerin analizinde tanımlayıcı istatistik (ortalama ve standart sapma), korelasyon analizi ve lojistik regresyon analizi kullanılmıştır. Çalışma sonuçlarına göre cinsiyet, eğitim, unvan ve kurum organizasyonel bağlıık düzeyi üzerinde etkin olan değişkenler olurken, eğitim, unvan, kurum, ilgili meslekte ve aynı kurumda çalışma süresi gibi faktörler iş tatmini üzerinde belirleyici olarak öne çıkmaktadır.
\end{abstract}

Anahtar Kelimeler: Sağlık Hizmetleri Personeli, Organizasyonel Bağılık, Iș Tatmini ve Demografik Özellikler.

Abstract: This study explores the relationships between the organizational commitment, job satisfaction and demographic characteristics through a sample of Turkish health care staff. The data were obtained by using sociodemographic data form, "Organizational Commitment Inventory" and "Minnesota satisfaction Scale" from 473 health care staff that have been working in 3 hospitals in Bursa. In the analysis of data, descriptive statistic (mean and standard deviation), correlation analysis and logistic regression analysis were used. In this study, the results show that gender, education, title 
and institution are effective on the organizational commitment level. In terms of job satisfaction, education, title, institution, duration of occupation and working in the same institution can be stated as diagnostic factors.

Keywords: Health Care Staff, Organizational Commitment, Job Satisfaction and Demographic Characteristics

\section{INTRODUCTION}

In the health sector, job satisfaction of the personnel and feeling of commitment are two of important factors for organizational productivity and profitability. But long term effects of these two parameters on productivity in health sector have been ignored for along time.

In the increasing competitive atmosphere of the 1980's health enterprises's choosing to terminate their workers' employment as an easy way of coping with a very basic problem like cost for the sake of both globalization and traditional personnel policies caused the relationship between health sector enterprises and their employees to get weaker. This subject, to which many researchers inclined towards, became the predictor of a tendency regarding the fact that two concepts like organizational commitment and job satisfaction were actually an effective tool of coping with problems. In many theoretical and empirical research studies carried out within this frame, it was made an attempt to reveal the multidimensional characteristic of the relationship between job satisfaction and organizational commitment relationship. The aim of this study is to explore the effects of demographic characteristics on organizational commitment and job satisfaction. But in Turkish literature especially in health sector, there are few studies examining organizational commitment and job satisfaction at the same time.

Örs's et al study (2003), investigated the effects demographic variables on organizational commitments of doctors and nurses; Cengiz's study (2002) investigated the association between demographic variables and organizational commitment among health care staff; Güçlü's study (2006) examined the effects of demographic characteristics on organizational commitment in tourism sector; Gümüş's et al. Study (2003) examined the association between demographic variables and organizational commitment in otel businesses; Çekmecelioğlu's study (2006) probed the effects of three components of organizational commitment and job satisfaction on intention to leave and productivity in four paint firms; Uyguç and Çımrın's study (2004) investigated the effects of organizational 
commitment on intention to leave among employees in center laboratory of DEÜ hospital; Türköz's study investigated the association between organization related attitude level, demographic variables and intent to stay among health care staff in hospital can be mentioned some of important studies relating to this subject. So it's understandable that there is not enough empirical datas on the possible effects of demographic and organizational variables on the organizational commitment and job satisfaction levels of health care staff. Therefore, one of the aims of this study is to address these informational deficiencies.

In study, the data were obtained by using a personel information form, "Organizational Commitment Inventory" and "Minnesota satisfaction Scale" from 473 health care staff that have been working in 3 hospitals. In the analysis of data, descriptive statistic (mean and standard deviation), correlation analysis, and logistic regression analysis were used.

In this way, the examination of the literature related to the subject and, later, the designation of sampling and empirical tests and finally reliability analysis results being put forth together with the results of empirical studies form the main stages of our study.

\section{ORGANIZATIONAL COMMITMENT IN THE LITERATURE}

Within the concept of "Organizational commitment", the word "commitment" has been used in many different meanings. Therefore, each different approach defines only a part of the dimensions of the concept related to the business enterprise. Buchanan (1974: 533), defining organizational commitment as " a partisan, affective attachment to the goals and values, and to the organization for its own sake, apart from its purely instrumental worth", reviews the concept under three dimensions, namely identificaiton, involvement and loyalty. According to this, identification refers to a person's adopting the goals and values of the organization and accepting them as his/her own goals and values; involvement refers to a person's participation into the organizational actvities and attachment to these psychologically while fulfilling his/her role entailed by his/her job; and loyalty refers to the symphaty and affective commitment a person's feels toward his/her organization.

Steers (1977: 46) defines organizational commitment as "the relative strength of an individual's identification with and involvement in a particular organization" and considers the organizational commitment as having two dimensions, namely attitudinal and behavioral. According 
to this, organizational commitment appears in the form of the individual's identification with the organization he/she is working in or for and the strength of the desire he/she exhibits in accordance with the goals and values of the organization. Strong attachment to the goals and expectations of the organization and acceptance of them, desire to spend remarkable effort in the name of the organization, and eventually the feeling of a strong desire to continue organizational membership are the factors composing the dynamics of the feeling of the organizational commitment (Porter, Steers, Mowday ve Boulian, 1974: 609).

For Mowday, Steers and Porter (1979: 224-247), organizational commitment refers to something more than a person's passive obedience to the organization. Forasmuch as the relation between the organization and the individual is active, and the individual may come to consent to make some sacrifices about themselves for their organization to be better (Mowday, Porter and Steers, 1982:27). This approach drawing attention to the relationship between organizational commitment and the psychological processes of the individual was supported by the findings of the study made by Meyer and Allen as well. According to this, organizational commitment has a psychological dimension and this relationship appears in the form of behaviours shaped depending on the relations of the workers with the organization and assuring their making-decision in the way of remaining continuous members of the organization (Meyer ve Allen, 1991: 61-89).

The dimensions of the psychological process urging an individual to attach to the organization can be formulated by a model formed under three headings, namely affective, continuance and normative (Meyer, Becker and Vandenberghe, 2004: 991-1007). In the model under discussion, affective commitment refers to individuals' desire to remain a part of the organization because of their emotional attachement to the organization, continuance commitment refers to the individuals' commitment to the organization because of their taking high costs of losing organizational membership, that is negative consequences, into account and their remaining members because they have to, and normative commitment refers to workers' feeling obliged to stay with the organization because of their having an ethical duty responsibility (Meyer ve Allen, 1997: 11).

In general, it appears that early studies on the subject tended to test the level of job satisfaction of employees and, in this direction, conceptualized employee satisfaction as "organizational commitment". However, it is observed that the studies investigating the concept "Organizational commitment" started especially in the 80's, and 
depending on the changing business and production environment, have been realised intensively from the 90's until today. In such studies, the variables, whose relationships with the organizational commitment have been investigated, can be summarized under five headings, namely demographic factors, job satisfaction factor, organizational factors, factors regarding roles and job experience factor.

The sub-headings that the studies, aiming to reveal the relatonship dimension between organizational commitment and demographic factors, have dwelt upon in general are age, education, gender and marital status. When the studies investigating the relationship between age and organizational commitment are examined, it can be said in general that in such studies the fact that age might have a positive effect on organizational commitment is emphasized. According to this, old-age workers' not prefering to change their employment compulsorily make them conservative, and in this direction, develop a reluctant attitude towards changing organization (Allen ve Meyer, 1993: 49-61; Hrebiniak ve Alutto, 1972: 563; Mayer ve Schoorman,1998: 15-28). To put it differently, it is possible that age creates a natural feeling of commitment in individuals depending on both experience and the conservative attitude it produces. For example, in another more detailed research study carried out on this matter with employees, a significant relationship was found between age and commitment. According to the study, aged employees compared to young ones were more committed to their jobs (Alutto, Hrebiniak ve Alonso, 1973: 448-454). However, there are also studies emphasizing the necessity of taking into account the effect of the workspace, seniority and status in addition to this result, that is the fact that age exhibits a positively correlated relationship with commitment (Bar-Hayım ve Berman, 1992: 379-387; Cohen ve Lowenberg, 1990: 1026-1027; Bowen, Radhakrishna ve Keyser, 1994).

While some of the studies conducted by taking into account the education variable indicate a linear relationship between education level and commitment, others appear to lay stress on lack of relationship(Buchko, Weinzimmer ve Sergeyev, 1998: 109-116; Örs, Acuner, Sarp ve Önder, 2003: 217-224) and negative relationship (Abdulla, 1999: 76-93; Morris ve Sherman, 1981: 512-526). In this context, it was observed that those with high education level are satisfied more difficultly, and since they have more job alternatives, they might not feel themselves committed to a single organization (Loscocco, 1990: 152-177; Wallace, 1997: 742). Other than this, there are also studies revealing the presence of a positive relationship between the 
highness of education level and individuals' levels of commitment to their jobs (Kömürcüoğlu, 2003).

However, it is observed that the studies, investigating the linkages between gender and organizational commitment, point out to the fact that the importance of the domain, created by a patriarchal settled culture based on the tradition of the woman's undertaking infamily functions like housekeeping chores and child care, and in contrast with this, the man's identification with a role of supporting his family by working outside, can not be denied. Because in such a cultural context, in working life, the woman participates in the competitive atmosphere under unequal conditions most of the time and this affects the woman's commitment to the job negatively (Ngo, Wing ve Tsang, 1998: 251-266).

However, when the traditional culture variable is disregard, it appears that while some of the studies made revealed that women compared to men are more committed to the job (Hrebiniak ve Alutto, 1972: 555-572), others put forward that gender is unrelated to organizational commitment (Güçlü, 2006: 211; Örs, Acuner, Sarp ve Önder, 2003: 217-224; Gümüş, Hamarat ve Erdem, 2003: 987-998). However, there are studies determining that men have more job commitment than women (Aranya, Kushnir ve Valency, 1986: 433-448; Türköz, sabem.saglik.gov.tr). In addition to these, the studies investigating that the possible effect of gender on commitment can change depending on the sector and position as well can not be ignored either. In this context, for example, it was determined that blue collar women have more organizational commitment than men, and in contrast to this, white collar men have more organizational commitment than women (Cohen, 1992: 539-554).

In the studies specifying that the values, which genders regard as more important in working life, have important effects on commitment as well, it was determined that men attach importance to the values like wage, autonomy and responsibility at work, and possessing an effective position in the organization, while women attach importance more to colleagues, communication with people, suitable working hours and job security (Scandure ve Lankau, 1997: 377-391). In the studies made with the aim of proving the relationship between gender and organizational commitment, that the differences arising on this head can grow out of the type of the job and the satisfaction the woman feels from her role in the family is not ignored (Loscocco, 1990: 152-177).

And in the studies predicating on the marital status variable, stress is laid on the fact that married women compared to unmarried 
ones might become more conservative. According to this, it was observed that workers with a family, because of a series of responsibilities they have taken on, refrained from taking the risks that are likely to make them lose their existing positions. The risk of workers' losing their jobs can be an indirect origin of a feeling of commitment (Huey, 2003).

The points, on which the studies discussing the effects of organizational factors on commitment focus in general, can be arranged as follows; work-content, management, colleagueness, organization environment, organization structure, possibility of participation in decisions, and empowering of workers. And in this context, the general opinion put forward is as follows; the variables, such as the meaning the of the job to the worker, possibility of participation in decisions, the feeling of commitment to coworkers, promotional opportunities (Guzley, 1992: 379-402; Brief ve Aldag, 1980: 210-221; Welsch ve Lavan, 1981: 1079-1089), and concerning the organization structure, low level of formalization and high level of decentralizated autonomy and finally the harmony of organization with environment have a positive effect on the concept of organizational commitment (Marsden, Kalleberg ve Cook, 1993: 384; Curry, Wakefield, Price ve Mueller, 1986: 847-858; Lambert, 2004: 208-227; Zeffane, 977-1010). Again in this context, it was indicated that supervisors had higher perceived variety, autonomy, feedback, dealing with others, and friendship opportunities scores and higher commitment and satisfaction scores than did nonsupervisory employees (Sneed ve Herman, 1990: 1072-1076).

The effects of the characteristics concerning workers and organization structure, which are included among the organizational factors pertaining to organizational commitment, were exemplified with the empirical research studies, revealing the positive relationship between the empowerment of workers and organizational commitment (Wilson, 1999: 120-137), and again, putting forward the fact that an organization structure, in which managers share their powers and knowledge with their subordinates and saddle them with some organizational responsibilities, strengthens the feeling of organizational commitment (Cohen, 1992: 539-554; Hackman ve Lawler, 1971: 259286; Niehoff, Enz ve Grover, 1990: 337-352). For example, again in this context, in the organizations, in which it is possible to get in touch with many peope all day and to work with other workers or other people, while it was observed that commitment was affected in a significantly positive way (Trombetta ve Rogers, 1988: 494-514). In addition to this, it's observed that in an organizational structure where getting 
informations and supports from the other managers, subworkers and benefiting from the other organizational resources are possible, managers being affected in a positive way can have high level sense of organizational commitment. (Cohen, 1992: 539-554; Mueller, Finley, Iverson ve Price, 1999: 187-219; Balfour ve Wechsler, 1990: 34-35; Walumbwa, Orwa, Wang ve Lawler, 2005: 235-256).

Another factor determining the feeling of organizational commitment is the ones regarding role. In the studies carried out on this matter, the factors like negative organizational atmosphere, uncertainty regarding role requirements, role conflict, inadequacy of organizational authority and influence, insufficiency of resources and possibilities, and within the organization, the impossibility to meet the interpersonal and social demands were dwelt upon. In this context, the effects of role uncertainty and role conflict on organizational commitment were put under investigation. In the studies made, it was found that these two factors affect organizational commitment negatively (Morris ve Sherman, 1981: 512-526; Gregersen ve Black, 1992: 65-90; Welsch ve Lavan, 1981: 1079-1089) and this effect can be less than expected (Glisson ve Durick, 1988: 61-81).

It has ben put forward that job experiences that an individual acquires have important effects on organizational commitment as well. The studies conducted on this matter indicate that first experiences an individual acquires after starting on a job affect greatly his/her commitment to the organization (Pierce ve Dunham, 1987: 163-167). In addition to this, the impossibility of using the vocational training, skills and experiences acquired in previous organization in next organization is considered to increase the rational commitment (Meyer ve Allen, 1984: 372-378).

In the literature, the indicators regarding human resources management and affecting the feeling of organizational commitment like performance, absenteeism and turnover rates and job satisfaction were regarded as other determining variables in addition to the aforementioned factors. When the studies that can be evaluated under this heading are examined, strong organizational commitment to be associated with desirable outcomes such as lower absenteeism and turnover (Mathieu ve Zajac, 1990: 171-194; Camp, 1993: 279-305), and it can be said that organizational commitment and satisfaction are in reciprocal relationship with each other (Bateman ve Strasser, 1984: 95112) and it can be put forward that the relationship between performance and commitment is very weak (Somers ve Birnbaum, 1998: 621-634; Steers, 1977: 46-56; Shaw, Delery ve Abdulla, 2003: 
1021-1030) and this relationship is affected more by the variables like economic conditions, and familial exigencies (Brett, Cron ve Slocum, 1995: 261-271).

\section{METHODOLOGY}

\subsection{Population Of The Study and Sample}

The population of the study comprised health care staffs that have been working in 2 public and 1 private hospitals in Bursa. The questionnaires were delivered to and collected from 750 health care staff which constitutes the universe of the study through hospital administration. The survey was conducted between May 1, 2006 and July 30,2006 . A total of 473 completed questionnaires were received back, giving a response rate of $63 \%$.

\subsection{Data Instruments}

In this study, data were collected using a personel information form and two different scales. Personal information data form was designed to gather information regarding gender, age, level of education, title, institution, years in occupation and years in institution. The first scale was the organizational commitment Inventory (OCI) which was developed by Mowday, Porter and Steers for measuring organizational commitment. It consists of 9 items. The items are scored on a five-point scale ranging from "strongly disagree" (1) to "strongly agree"(5). A general score is then determined by acquiring the mean score from the 9 responses after reverse scoring three negatively phrased questions. The coefficient alphas for organizational commitment were 0,596. The second scale was the short form of Minnesota satisfaction Scale which was developed by Weiss, Dawis, England, and Loftquist (1967) to measure intrinsic satisfaction, extrinsic satisfaction and general satisfaction. The intrinsic satisfaction subscale consists of twelve items which describe satisfaction feelings of ability utilization, activity, achievement, authority, independence, moral values, responsibility, security, creativity, social service, social status and variety. The six items on the extrinsic satisfaction subscale describe satisfaction feelings of advancement, company policy, compensation, recognition, supervision-human relations and supervision-technical. The general satisfaction consists of twenty items, describing satisfaction feelings of working conditions, co-workers, intrinsic satisfaction, and extrinsic satisfaction. The short form of the MSQ includes 20 items that are relevant to a number of job facets; respondents indicate their degrees of relative satisfaction using a 5-point, Likert-type scale ranging 
from 1 (very dissatisfied) to 5 (very satisfied). The average of the 20 items formed overall job satisfaction. The coefficient alphas for overall job satisfaction, intrinsic satisfaction, and extrinsic satisfaction were $.893, .841$ and .770 , respectively.

\subsection{Analysis of Data}

The data were analyzed by using SPSS 13 (The Statistical Package for Social Sciences). The descriptive data analysis was conducted by calculating frequencies, mean scores and standard deviations for determining organizational commitment and job satisfaction levels of the respondents. Pearson correlations were calculated to examine the associations among the organizational commitment and job satisfaction scales. Also this study investigated the relationship and differences between the levels of organizational commitment and job satisfaction and demographics characteristics among Turkish health care.

\subsection{Findings}

The findings of the study were examined in two sections. In the first section, the demographic characteristics of the respondents were presented and in the second section, the results of the analyses were presented.

\subsubsection{Demographic characteristics of the respondents}

Demographic characteristics of the sample are shown in Table 1. The table shows the distribution of respondents by gender, age, level of education, institution (public or private hospital), title, years in institution and years in occupation.

As seen Table $1,77.5 \%$ of the respondents were female and $22.5 \%$ of the respondents were male. According to the age of personnel, $4 \%$ of the respondents were under 20 years of age, $38.6 \%$ of the respondents were between $21-30$ years of age, $37.9 \%$ of the respondents were between $31-40$ years of age, $19.5 \%$ of the respondents were 41 or above years of age. According to the level of education, $35.5 \%$ of respondents had technical school degree, \%33.4 of the personnel had high school degree, $16.1 \%$ of personnel had university degree, $13.5 \%$ of personnel had master degree or above. According to title, $43,1 \%$ of the respondents were nurse, $16,7 \%$ of the respondents were specialist doctor, $12,7 \%$ of the respondents were Other health care staff. While $70.8 \%$ of the participants had worked in a public hospitals, $29,2 \%$ of the participants had worked in a private 
hospital. According to the years in occupation, $30.1 \%$ of the participants were more than 16 years, $22,3 \%$ of the participants were between $6-10$ years, $20,2 \%$ of the participants had been working between $11-15$ years in same occupation. According to the years in institution, $38.3 \%$ of participants were between $1-5$ years, $26.1 \%$ of participants were between $6-10$ years, $14.6 \%$ of the participants had been at the institution for less than 1 years.

\subsubsection{Organizational commitment and job satisfaction scores of health care staff}

In Table 2, the organizational commitment, general satisfaction and two satisfaction subscales' means, minimum, maximum values and standard deviations of the health care staff which participated in the research have been presented. As seen in Table 2, four different mean scores were calculated; organizational commitment score, general satisfaction score, intrinsic satisfaction score, extrinsic satisfaction score. According to this, the mean scores for organizational commitment, general satisfaction, intrinsic satisfaction, extrinsic satisfaction was $3.3392(\mathrm{SD}=, 54479), \quad 3.0284(\mathrm{SD}=, 80529)$, $3.3573(\mathrm{SD}=, 62577)$, and $3.5364(\mathrm{SD}=, 62337)$ respectively. These mean figures show us that the health care staff have the extrinsic satisfaction at a above medium level, intrinsic satisfaction, organizational commitment and general satisfaction at a medium level. These mean scores show that health care staff have extrinsic satisfaction with the highest mean degree. Health care staff's intrinsic satisfaction, organizational commitment and general satisfaction are the other subsequent parameters. The low general satisfaction stem from the low satisfaction scores to work place conditition and co-workers.

In Table 3 , the correlations between general satisfaction, intrinsic satisfaction, extrinsic satisfaction and organizational commitment of the health care staff are presented. The numbers which are marked with an asterix in the table show that according to the significance level $1 \%$, there is a meaningful relationship between the variables. According to this, the relationship between the organizational commitment, general satisfaction and two satisfaction subscales of the health care staff is a significance level and the relations degree realized in order as $0,485(p<0,01), 0.575(p<0,01), 0,544(p<0,01)$. Also, there is a meaningful level of high relationship between the intrinsic satisfaction, general satisfaction and extrinsic satisfaction of health care staff. The relationship between general satisfaction and two satisfaction subscales are significant, but lower. 


\subsubsection{Multiple Regression Analysis}

To test the effect of demographics characteristics on the organizational commitment, general satisfaction and two satisfaction subscales levels in a sample of health care staff, the following multiple regression was run:

$y=\beta_{0}+\beta_{1} x_{1}+\beta_{2} x_{2}+\beta_{3} x_{3}+\beta_{4} x_{4}+\beta_{5} x_{5}+\beta_{6} x_{6}+\beta_{7} x_{7}+\varepsilon^{1}$

When the OC regression model in Table 4 is looked at we reach the result that almost $4.2 \%$ of the changes on the level of organizational commitment are created by the health care staff's demographics characteristics which we have included in the model. When the $\mathrm{F}$ value in the table is looked at it is observed that there is a meaningful relationship between the level of organizational commitment and demographics characteristics. $(p<0,05)$ When the effect of each independent variable in the model is examined, it can be seen that to express the level of organizational commitment, apart from the health care staff's years in occupation, other parameters don't have any significance of their own. $(p<0,05)$ When the beta values are looked at which are standardized co efficiency in the table, it is seen that years in occupation variable affect the level of organizational commitment in a negative direction on the significance level of $p<0,05$ with the beta co efficiency of $-0,111$

Table 4 shows that, almost $12,3 \%$ of the realized probable changes on the level of general satisfaction of health care staff are expressed by independent variables which participated in the model. And when the $\mathrm{F}$ statistical value is looked at it is seen that there is a meaningful relationship between the level of the general satisfaction and independent variables. When $t$ values are looked at to evaluate the effect of each independent variable on the aforementioned dependent variable, it is seen that apart from the health care staff's age, education level and Institution, other parameters have singular meaningfulness to express the dependent variable. $(p<0,05)$ The beta value in Table 4 , expresses that the health care staff's age, education level affects in a positive direction the level of general satisfaction significance level of $p<0,05$ with the beta co efficiency in order as 0,303 and ,071. But when it is taken into consideration that the health care staff's Institution variable affect in a negative direction the level of general satisfaction at

\footnotetext{
${ }^{1}$ Model explains $\beta_{0}=$ Constant, $Y=$ organizational commitment, general satisfaction and two satisfaction subscales, $x_{1}=$ participant's age, $x_{2}=$ gender, $x_{3}=$ education level, $x_{4}=$ title, $x_{5}=$ institution, $x_{6}=$ years in occupation, $x_{7}=$ years in institution
} 
the significance level of $p<0,05$, with the beta co efficiency such as ,089. it is possible to accept the hypothesis that the Institution variable don't affect in a positive direction the level of general satisfaction.

When we looked at the IS model in Table 4, almost $5 \%$ of the changes in the level of Interior Satisfaction are expressed by used independent variables or else it can be said these variables express the $8.8 \%$ of changes. Together with this, $F$ value expresses that the established model is meaningful as statistical. $(p<0,05)$ When the $t$ values are examined, it is seen that apart from age and education level, all independent variables parameters don't have singular significance to describe the dependent variable $(p<0,05)$. When beta values which are standardized co efficiency are looked at in the Table, it can be seen that the health care staff's age, education level affects in a positive direction the level of interior satisfaction significance level of $p<0,05$ with the beta co efficiency in order as ,277 and ,069.

When the ES model in Table 4 is examined, it can be seen that almost $11,8 \%$ of the changes related to the level of extrinsic satisfaction of health care staff are expressed by the independent variables which were included in the model. $F$ value shows that the established model is meaningful $(p<0,05)$. And when the $t$ values are looked at apart from age and institution, all the other parameters have no singular significance to express the level of extrinsic satisfaction of health care staff which can be observed. $(p<0,05)$ When the beta value is looked at in the table, it is seen that the health care staff's age affects in a positive direction the level of extrinsic satisfaction at significance level of $p<0,05$ with the 0,351 beta co efficiency. But when it is taken into consideration that the health care staff's institution variable affects in a negative direction the level of extrinsic satisfaction at the significance level of $p<0,05$, with the beta co efficiency such as,- 158

\subsubsection{Results of the t-Test and ANOVA}

In this section, we explore whether there were differences between demographic variables (gender, age, level of education, institution, title, years in institution and years in occupation) and organizational commitment and job satisfaction scales. In this aim, t-test and one-way variance (ANOVA) analysis were used and Tukey (equal variances assumed) and Tamhane (equal variances not assumed) tests were conducted to examine group differences for above independent variables with two or more levels. The results of the analysis were presented in Table 4. 
According to the gender of health care staff, t-test results in Table 4 showed that there was a significant difference between organizational commitment level of female and organizational commitment level of male. The organizational commitment level of men health care staff was higher than woman health care staff. However, there was no significant difference between job satisfaction levels of female and job satisfaction levels of male.

There was no significant difference in organizational commitment, general satisfaction, exterior satisfaction and interior satisfaction according to age.

According to the level of education, there were significant differences in the levels of organizational commitment, general satisfaction, exterior satisfaction and interior satisfaction. Tukey test showed that organizational commitment scores of health care staff who had technical school were lower than health care staff who had university degree and master and above degree. However, general satisfaction, exterior satisfaction and interior satisfaction levels of health care staff who had high school and technical school degree were lower than health care staff who had university degree and master and above degree.

Title was found to be another demographic variable that was related to organizational commitment, general satisfaction, exterior satisfaction and interior satisfaction. Tamhane test showed that specialist doctors, practitioner doctors and health officers tended to show greater organizational commitment feeling than nurses. However, general satisfaction and exterior satisfaction scores of specialist doctors, practitioner doctors and other healthcare staff were higher than nurses, accoucheur, administrative officer and technical officer and the interior satisfaction scores of specialist doctors, administrative officer and other healthcare staff were higher than nurses, accoucheur and technical officer.

According to the Institution, there was meaningful difference in all dependent variables. Tukey test showed that organizational commitment, general satisfaction and interior satisfaction scores of private hospital were higher than public hospitals and the exterior satisfaction scores of private hospital and public hospitals-1 were higher than public hospitals-2.

According to the years in the occupation and institution, while there was not a significant difference in organizational commitment, general satisfaction and interior satisfaction, there was a meaningful 
difference in exterior satisfaction. Tukey test showed that exterior satisfaction scores of health care staff who had been working for under 1 year and between 11-15 years in profession and institution were higher than health care staff who had been working for more than 16 years.

\section{DISCUSSION and CONCLUSION}

Organizational commitment and job satisfaction levels of health care staff and the relationship and differences between demographic characteristics and organizational commitment and job satisfaction levels were investigated in this study. The population for this study comprised of health care staff from 3 hospitals in Bursa. For the aim of the study, three questionnaires were used (sosciodemographic data form, "organizational commitment inventory" and the scale of "Minnesota satisfaction scale") and these questionnaires were distributed to 750 health care staff. 473 health care staff responded the questionnaires. The response rate was $63 \%$. In the analysis of data, descriptive statistic (mean and standard deviation), correlation analysis, and logistic regression analysis were used.

According to the means and standard deviations, the health care staff have the extrinsic satisfaction are at above medium level, intrinsic satisfaction, organizational commitment and general satisfaction at a medium level. Particularly, the level of general satisfaction was rather low. The low score on general satisfaction stems from the low satisfaction scores to working conditions and co-workers.

The regression models which were constituted for determining the relationships between organizational commitment, job satisfaction and demographic factors. According to the regression tables, it is possible to make these evaluations directed towards the relationship between the variables: There is a meaningful relationship between health care staff's age and general satisfaction and two satisfaction subscales levels. And also it can be said that there is an important relationship between the health care staff's education level and the levels of general satisfaction and interior satisfaction. But a meaningful relationship is not seen between the institution variable and level of general satisfaction and extrinsic satisfaction of health care staff. Also, a reverse relationship is seen between the years in occupation variable and the level of organizational commitment of health care staff. In general, the above established four models describe in order $4.2 \%$, $12.3 \%, 8.8 \%, 11.8 \%$ of the changes in the levels of organizational commitment, general satisfaction and two satisfaction subscales. 
However, the results of ANOVA showed that there was a significant difference in organizational commitment according to the gender, level of education, institution and title $(p<0,05)$. In point of gender the results of study show that men have more organizational commitment than women among the health care staff. In addition, there is a positive linkage between education level and health care staff organizational commitment levels. In other words, health care staff had university, master and upper degree have more organizational commitment than others. In point of institution, private hospital'staff has more organizational commitment than public hospitals. By taking into account the title variables, it's observed that specialist doctors, practitioner doctors and other healthcare staff tended to show greater organizational commitment feeling than nurses.

Also, there was a significant difference in general satisfaction and two subscales according to the level of education, institution and title $(p<0,05)$. If it's more clearly stated, health care staff had university, master and upper degree have more job satisfaction levels in comparison to the other education levels. In addition, specialist doctors, practitioner doctors and other healthcare staff were higher job satisfaction levels than others. In point of institution, health care staff had been working in private hospitals were higher job satisfaction levels compared to public hospitals. Also the results showed that exterior satisfaction scores of health care staff who had been working for under 1 year and between 11-15 years in profession and institution were higher than health care staff who had been working for more than 16 years.

Organizational commitment and job satisfaction are especially important issues in service sector, because the organizational commitment and job satisfaction is associated with the operative effect, productivity, and service quality of the organization, and accordingly customer satisfaction increases. Therefore health care administrators and academicians are aware of organizational commitment feeling and deal with it openly. There has been a large number of studies of organizational commitment, but health care staff organizational commitment is an area which still needs to be studied further. The studies related to organizational commitment among health care staff can help and guide to both health care administrators and academicians. 


\section{REFERENCES}

Abdulla, Mohamed H.A. (1999), "Personal Factors And Organizational Commitment: Main And Interactive Effects In The United Arab Emirates", Journal of Managerial Issues, Spring 99, Vol.11, Issue 1, pp.76-93.

Allen, Natalie J. and Meyer, John P. (1993), "Organizational Commitment: Evidence Of Career Stage Effects", Journal Of Business Research, Vol.29, Issue: 1, January 1993, pp. 49-61.

Alutto, Joseph A., Hrebiniak, Lawrence G. and Alonso, Ramon C. (1973), "On Operationalizing The Concept of Commitment", Social Forces, Vol.51, No: 4, Jun., 1973, pp.448-454.

Aranya, Nissim, Kushnir, Talma and Valency, Aharon (1986), "Organizational Commitment in A Male-Dominated Profession" Human Relations, Volume 39, Number 5, pp.433-448.

Balfour, Danny L. and Wechsler, Barton (1990), "Organizational Commitment: A Reconceptualization And Empirical Test Of Public-Private Differences", Review Of Public Personnel Administration, Vol.10; No.23, pp.34-35.

Bar-Hayım, Aviad and Berman, Gerald S. (1992), "The Dimensions Of Organizational Commitment, Journal of Organizational Behavior, Vol.13, 1992, pp.379-387.

Bateman, Thomas S. and Strasser, Stephen (1984), "A Longitudinal Analysis Of The Antecedents Of Organizational Commitment", The Academy of Management Journal, Vol.27, No.1, March, pp. 95-112.

Bowen, Cathy F., Radhakrishna, Rama and Keyser, Robin (1994), "Job Satisfaction And Commitment Of 4-H Agents", Journal of Extension, Volume 32, Number:1, June 1994.

Brett, Joan F., Cron, William L. and Slocum, John W. Jr. (1995), "Economic Dependency On Work: A Moderator Of The Relationship Between Organizational Commitment And Performance", Academy of Management Journal, Vol. 38, No.1, pp.261-271.

Brief, Arthur P. and Aldag, Ramon J. (1980), "Antecedents of Organizational Commitment Among Hospital Nurses", Sociology of Work And Occupations, Vol: 7, No: 2, May 1980, pp.210-221.

Buchanan II, Bruce (1974) "Building Organizational Commitment: The Socializaion of Managers in Work Organizations", Administrative Science Quarterly, volume:19, Issue: 4, pp.533. 
Buchko, Aaron A., Weinzimmer, Laurence G. and Sergeyev, Alexander V. (1998), "Effects Of Cultural Context on The Antecedents, Correlates, and Consequences of Organizational Commitment", Journal of Business Research, Vol. 43, Issue 3, November 1998, pp.109-116.

Camp, Scott D. (1993) "Assessing the Effects of Organizational Commitment and Job satisfaction on Turnover: An Event History Approach", The Prison Journal, Vol.74, No: 3, pp.279-305.

Cengiz, Aytül Ayşe (2002) "Örgüt Yaşamında Örgütsel Bağııı̆̆ın Belirleyicileri ve Eskişehir Bölgesinde Doktor ve Hemşire Meslek Grupları Arasında Karşılaştırmalı Bir Çalışma”, 10 Ulusal Yönetim Kongresi Bildiri Kitabı, 23-25 Mayıs 2002, s. 805-817.

Cohen, Aaron (1992) "Antecedents Of Organizational Commitment Across Occupational Groups: A Meta-Analysis”, Journal of Organizational Behavior, Vol. 13, pp.539-554.

Cohen, Aaron and Lowenberg, Geula (1990), "A Re-Examination Of The SideBet Theory As Applied To Organizational Commitment: A Meta-Analysis", Human Relations, Vol. 43, Number 10, pp.1026-1027.

Curry, James P., Wakefield, Douglas S., Price, James L., Mueller, Charles W. (1986), "On The Causal Ordering Of Job Satisfaction And Organizational Commitment", The Academy Of Management Journal, Vol. 29, No. 4. (Dec., 1986), pp. 847-858.

Glisson, Charles and Durick, Mark (1988) "Predictors of Job Satisfaction and Organizatioanl Commitment in Human Service Organizations", Administrative Science Quarterly, March 1988, pp.61-81.

Gregersen, Hal and Black, Stewart (1992) "Antecedents To Commitment To A Parent Company And A Foreign Operation", Academy of Management Journal, Vol.35, No.1, 1992, pp.65-90.

Guzley, Ruth M. (1992), "Organizational Climate And Communication Climate Predictors Of Commitment To The Organization", Management Communication Quarterly, Vol.5, No.4, May 1992, pp.379-402.

Güçlü, Hatice (2006), Turizm Sektöründe Durumsal Faktörlerin Örgütsel Bağlılık Üzerindeki Etkisi, T.C. Anadolu Üniversitesi Yayınları, No: 1681, Eskişehir, s.211.

Gümüş, Murat, Hamarat, Bahattin ve Erdem, Haluk (2003), “Örgütsel Bağlılığın İs Mükemmelliği ile Illişkisinin Otel İşletmelerinde Belirlenmesine Yönelik Bir 
Araştırma", 11 Ulusal Yönetim ve Organizasyon Kongresi, Afyon: Afyon Kocatepe Üniversitesi, (22-24 Mayıs 2003), s.987-998.

Hackman, J.R., Lawler, Edward E. (1971) "Employee Reactions To Job Characteristics", Journal of Applied Psychology, Vol.55, pp..259-286.

Hrebiniak, Lawrence G. and Alutto, Joseph A. (1972), "Personel And RoleRelated Factors in The Development Of Organizational Commitment", Administrative Science Quarterly, Vol.17, Issue: 4 (December 1972), pp.563.(555-572).

Huey, Jerry Dwayne (2003), "The Influence Of Family Responsive Practices On Job Satisfaction, Organizational Commitment, And Intentions To Turnover For Working Women With Children",www.Digitalcommons Columbia.

Kömürcüoğlu, Hüseyin (2003), "Belirsizlik Ortamında iş Tatmini ve Işse Bağlıık", "iş, güç" Endüstri Illişkileri ve Insan Kaynakları Dergisi, Cilt: 5, Sayı: 1.

Lambert, Eric G. (2004), "The Impact of Job Characteristics On Correctional Staff Members", The Prison Journal, Vol. 84 No. 2, June 2004 pp.208-227.

Loscocco, Karyn A. (1990), "Reactions To Blue-Collar Work A Comparison of Women and Men" Work and Occupations, Vol.17, No:2, May 1990, pp.152177.

Marsden, Peter V., Kalleberg, Arne L. and Cook, Cynthia R. (1993), "Gender Differences in Organizational Commitment: Influences of Work Positions And Family Roles", Work and Occupations, Vol.20, No.3, August 1993, pp.384(368390).

Mathieu, J.E. and Zajac, D.M. (1990), "A review and meta-analysis of the antecedents, correlates, and consequences of organizational commitment", Psychological Bulletin, 108, 171-194.

Mayer, Roger C. and Schoorman, F. David (1998), "Differentiating Antecedents of Organizational Commitment: A Test of March And Simon's Model", Journal of Organizational Behavior, Vol. 19, pp.15-28.

Meyer, J. P. \& Allen, N. J. (1997). Commitment in the workplace: Theory, Research, and Application, Thousand Oaks, CA: Sage Publications, s.11

Meyer, J. P. and Allen, N.J. (1991), "A three-component conceptualization of organizational commitment", Human Resource Management Review, 1, 61-89. 
Meyer, John P. and Allen, Natalie J. (1984), "Testing the "Side-Bet" Theory of Organizational Commitment: Some Methodological Implications", Journal of Applied Psychology, Vol. 69, No: 3 (Aug. 1984), pp.372-378.

Meyer, John P., Becker, Thomas E. and Vandenberghe, Christian (2004) "Employee Commitment and Motivation: A Conceptual Analysis and Integrative Model", Journal of Applied Psychology, Vol. 89, No. 6, 991-1007.

Morris, James H. and Sherman, J. Daniel (1981), "Generalizability of An Organizational Commitment Model", Academy of Management Journal, Vol.24, No.3, pp.518 (512-526).

Mowday, R.T., Porter, L.W. and Steers, R.M., (1982), "Employee Organization Linkages: The Psychology of Commitment, Absenteeism, and Turnover, Academic Press, New York, p.27.

Mowday, R.T., Steers, R.M. and Porter, L.W.(1979), "The Measurement of Organizational Commitment”, Journal of Vocational Behavior, Vol.14, pp.224247.

Mueller, Charles W., Fınley, Ashley, Iverson, Roderıck D. and Price, James L. (1999), "The Effects Of Group Racial Composition On Job Satisfaction, Organizational Commitment, And Career Commitment: The Case of Teachers", Work And Occupations, Vol. 26 No. 2, May 1999, pp.187-219.

Ngo, Hang-Yue, Wing, Anita and Tsang, Ngar (1998), "Employment Practices and Organizational Commitment: Differential Effects for Men a Women?", The International Journal of Organizational Analysis, Vol.6, No: 3, July 1998, pp.251-266.

Niehoff, B.P., Enz, C.A., Grover, R.A. (1990) "The Impact Of Top Management Actions On Employee Attitudes And Perceptions", Group\&Organization Management" September 1990, Vol.15, Issue.3, pp.337-352.

Örs, Mukaddes, Acuner, Ahmet Münir, Sarp, Nilgün and Önder, Öner Rıfkı (2003), "Antalya Tıp Fakültesi Hastanesi'nde, Antalya Sosyal Sigortalar Kurumu Hastanesi'nde ve Antalya Devlet Hastanesi'nde Çalışan Hekimler ile Hemşirelerin Örgütlerine Bağlılıklarına İlişkin Görüşlerinin Değerlendirilmesi”, Ankara Üniversitesi Tıp Fakültesi Mecmuası, Cilt 56, Sayı: 4, 2003, s.217-224.

Pierce, Jan and Dunham, Randall (1987) "Organizational Commitment: PreEmployment Propensity and Initial Work Experiences", Journal of Mangement, V.13, No: 1, 1987, pp. 163-167. 
Porter, L.W., Steers, R.M., Mowday, R.T. and Boulian, P.V. (1974) "Organizational Commitment, Job Satisfaction, and Turnover among Psychiatric Technicians, Journal of Applied Psychology, Vol.59, s.609.

Scandure, Terri A. and Lankau, Melenie J. (1997), "Relationships of Gender, Family Responsibility And Flexible Work Hours to Organizational Commitment and Job Satisfaction", Journal of Organizational Behavior, Vol. 18, pp.377-391.

Shaw, Jason D., Delery, John E. and Abdulla, Mohamed H.A. (2003), "Organizational Commitment And Performance Among Workers and Citizens Of An Arab Country", Journal of Business Research, Volume: 56, Issue: 12, December 2003, pp.1021-1030.

Sneed J., Herman CM (1990), "Influence Of Job Characteristics And Organizational Commitment On Job Satisfaction Of Hospital Foodservice Employees", J Am Diet Assoc., Aug. 1990(8), pp.1072-1076.

Somers, Mark John and Birnbaum, Dee (1998), "Work-Related Commitment and Job Performance: It's Also The Nature Of The Performance That Counts", Journal of Organizational Behavior, 19, pp.621-634.

Steers, Richard M. (1977), "Antecedents and Outcomes of Organizational Commitment", Administrative Science Quarterly, March 1977, Volume 22, pp.46-56.

Trombetta, John J. and Rogers, Donald P. (1988), "Communication Climate, Job Satisfaction, and Organizational Commitment: The Effects Of Information Adequacy, Communication Openness, and Decision Participation", Management Communication Quarterly, Vol.1, No.4, May 1988, pp.494-514.

Türköz, Yeşim "Özel Bir Sağlık Kuruluşunda Işe ve Kuruma Yönelik Tutum Araştırması", Hacettepe Sağlık idaresi Dergisi, Cilt: 3, pp.64-90, www.sabem.saglik.gov.tr/akademik metinler/goto.

Wallace, Jean E. (1997), "Becker's Side-Bet Theory Of Commitment Revisited: Is It Time For A Moratorium or A Resurrection?", Human Relations, Vol. 50, No.6, pp.742.

Walumbwa, Fred O., Orwa, Bani, Wang, Peng and Lawler, John J. (2005), "Transformational Leadership, Organizational Commitment, And Job Satisfaction: A Comparative Study Of Kenyan And U.S. Financial Firms", Human Resource Development Quarterly, Volume 16, Issue:2, pp.235-256.

Welsch, Harold P. and Lavan, Helen (1981), "Inter-Relationships Between Organizational Commitment and Job Characteristics, Job Satisfaction, 
Professional Behavior, And Organizational Climate", Human Relations, Volume:34, Number: 12, pp.1079-1089.

Wilson, Patricia (1999) "A Theory Of Power And Politics And Their Effects On Organizational Commitment Of Senior Executive Service Members", Administration and Society, Vol. 31, Issue.1, March 1999, pp.120-137.

Zeffane, Rachid (), "Patterns Of Organizational Commitment And Perceived Management Style: A Comparison Of Public and Private Sector Employees", Human Relations, Vol.47,No.8, pp.977-1010. 